\title{
The Needs of Educators in Intercultural and Bilingual Preschools in Chile: A Case Study
}

\author{
Rukmini Becerra-Lubies \\ Pontificia Universidad Católica de Chile \\ Chile
}

Aliza Fones
University of Washington

U. S. A.

ABSTRACT: Several studies have examined the lack of or the insufficient preparation of K-12 educators to work in intercultural and bilingual (IBE) schools in Chile, but little is known about the preparation of educators to teach in IBE preschools. Even less is known about teachers' perceptions of their own preparation. This work contributes to a growing body of literature that examines the experiences and practice of second language teachers in Indigenous language education settings from a sociocultural perspective. This qualitative case study focuses on teachers' perceptions of their preparation to teach Mapudungun, the language of the Mapuche people, in urban IBE preschools in Chile. Three research questions guide this study: What are teachers' perceptions of their needs regarding their preparation to teach Mapudungun in urban IBE preschools? What are the current challenges that teachers face teaching Mapudungun in urban IBE preschools? Which experiences fostered their ability to teach Mapudungun? The findings of this study have implications for the incorporation of more complex notions of Indigenous language learning that are linked directly to Mapuche culture and its sociopolitical context, as well as the inclusion of teachers' experiential knowledge in the preparation of teachers for work in IBE schools.

KEYWORDS: teacher education, intercultural and bilingual education, Indigenous language, preschools, Mapuche people.

Framing Literature and Concepts

Design and Methods

Findings and Discussion

Conclusions

Looking Forward: Implications for the Preparation of Teacher for IBE preschools

Acknowledgements

Notes

References

Author Contact 
Although Chile is multiethnic and multicultural, governmental policies and programs that focus specifically on the education of Indigenous students are only a recent addition to Chile's educational system. Since 1992, the Intercultural and Bilingual Education (IBE) program is the primary program that the Chilean Ministry of Education has implemented for improving the education of Indigenous students; ${ }^{1}$ it is also important to note that IBE preschools were only recently created, in 2009 (Bustos, Cariman, Díaz, \& Merino, 2014). Despite the benefits of these efforts, a growing number of reports and studies have identified crucial problems with the IBE program (Fernández, 2005; Ministerio de Educación, 2011; UNICEF \& Ministerio de Desarrollo Social, 2011). One problem is the insufficientand sometimes inappropriate-preparation for K-12 teachers working in IBE schools (Abarca, Alarcón, Huircán, Millacura, \& Olivares, n.d.; Programa de Educación Intercultural Bilingüe, Ministerio de Educación, \& UNICEF, 2012; Turra, Ferrada, \& Villena, 2013). In addition, relevant research on teacher education for IBE settings is limited in Chile, with few of these studies focused specifically on the preparation of teachers to teach in IBE preschools.

The small number of relevant studies, as well as their findings with respect to insufficient teacher preparation, are not surprising if we consider that university programs for teacher education in IBE schools are very limited in Chile. There are only two such programs in Chile, and neither of them is located in Región Metropolitana, the capital region, even though this region has the fastest growing population of Indigenous people in the country. This lack of teacher education programs for IBE in Región Metropolitana suggests that preschool teachers may face crucial issues when teaching in IBE preschools. First, these teachers may not have received relevant or adequate linguistic and cultural preparation for IBE; second, they will be teaching in an area-Región Metropolitana-that sees itself as a "white" and "modern" city, while rejecting and ignoring the presence of native Mapuche people (Aravena, 2007). In short, these teachers are not professionally prepared, and they may not be even aware of diversity and Indigenous children in their schools, despite the widely researched importance of culturally responsive pedagogy in teacher preparation programs (e.g., Cochran-Smith, 2004; Gay, 2002, 2010; Villegas \& Lucas, 2002).

To address these issues, we focused this study on preschool education, as this is the only level that acknowledges IBE education from the standpoint of an entire school as opposed to the mainstream elementary and secondary schools in Chile that offer a single course or class on Indigenous language and culture. Additionally, we focused on IBE preschools because Indigenous communities in Chile consider the education of young children as crucial for the revitalization of Indigenous languages.

In this study, we aim to identify teachers' perceptions of their needs regarding their preparation to teach language (specifically, Mapudungun) in emergent bilingual settings, such as IBE preschools. This study is focused on the Mapudungun language as it is the language of Mapuche people; it is one of the 
most widespread Indigenous languages spoken in the country. ${ }^{2}$ The following are the three research questions guiding this case study:

1. What are teachers' perceptions of their needs regarding their preparation to teach Mapudungun in urban IBE preschools?

2. What are the current challenges these teachers face while teaching Mapudungun in urban IBE preschools?

3. Which experiences have been the most supportive and helpful to teachers or, in other words, which experiences have fostered their ability to teach Mapudungun in the preschool where they work?

This study addresses in part the directive of the IBE program in Chile to develop additive bilingualism in children (Loncon, Ministerio de Educación, \& Programa de Educación Intercultural Bilingüe, 2011), which promotes the learning of linguistic and communicative skills in an Indigenous language in addition to Spanish, while also encouraging the transfer of the linguistic skills of the first language into the second language. It is important to note that while this study examined the perceptions of preschool educators regarding additive bilingualism, research has shown that most students in IBE schools in fact do not become bilingual (Ministerio de Educación, 2011).

Additionally, little attention has been paid to the perceptions and experiences of in-service teachers, prioritizing the experiences of pre-service teachers in the two existing preparation programs for K-12 teachers in IBE schools in Chile. ${ }^{3}$ These studies have focused on problems of teacher education programs (Hernández, 2007; Quilaqueo \& Quintriqueo, 2008); pre-service teachers' attitudes towards teaching and learning an Indigenous language (Olate \& Henríquez, 2010), and identifying pieces of Indigenous knowledge that pre-service teachers should learn (Carihuentro, 2007; Quilaqueo \& Quintriqueo, 2008, 2010).

Understanding in-service teachers' perceptions of their needs is imperative for improving teacher preparation for Indigenous education. This is a particularly salient issue in Chile, where the lack of teacher education programs for IBE schools perpetuates the existing inequalities faced by Mapuche children (Catriquir, 2014; Ibáñez, 2015).

In summary, understanding teachers' experiences and their perceptions of their preparation to work in IBE schools has the potential to infuse teacher education in Chile with insider knowledge, the complex and multilayered understanding of their work settings that teachers possess (Johnson, 2006). This insider knowledge is especially valuable since it emerges from teachers' lived experiences, teachers' perceptions of their work, and the problems of practice situated in the context where the problems arise. 


\section{Framing Literature and Concepts}

To frame this study, we draw from relevant sociocultural theories that allow us to explicate and analyze the participants' knowledge, experiences, and learning of IBE educators. We begin with a description of sociocultural perspectives on teacher education and the importance of applying these perspectives in the IBE school setting, followed by a closer examination of sociocultural theories applied to second language teachers.

\section{Sociocultural Perspectives on Teacher Education for IBE Schools}

The call to incorporate sociocultural perspectives into teacher education has been present for many years (Lewis, Enciso, \& Moje, 2007). In fact, within sociocultural perspectives at large, there is a growing body of literature that supports and promotes the incorporation of teachers' lived experiences as a way to overcome the inadequate preparation of teachers working in diverse settings (e.g., Au, 2002; Boyle-Baise, 1998; Zeichner, 2010).

Though the field of teacher education for IBE schools in Latin America has seen important developments in recent years, most studies conducted in Chile and neighboring countries have attempted to improve this field by proposing certain skills, attitudes, and knowledge that teachers should possess (see Table 1). However, these studies exclude the experiences and knowledge that teachers gain during their daily practices, as well as the knowledge that they bring with them to the profession. The following table summarizes the proposals of several authorsIpiña Melgar (1997), López (1997), Schmelkes (2007), Serrano (1998), and Trapnell (2003)—regarding the ideal knowledge, skills, and attitudes for teaching children in an IBE setting.

Table 1

Summary of Proposed Knowledge, Skills and Attitudes that Teachers Should Possess in IBE Schools

\begin{tabular}{|c|c|c|}
\hline Skills & Attitudes & Knowledge \\
\hline $\begin{array}{l}\text { Teachers are able to: } \\
\text { - continue } \\
\text { professional } \\
\text { development. } \\
\text { - conduct research in } \\
\text { their classrooms. }\end{array}$ & $\begin{array}{l}\text { Teachers are committed to: } \\
\text { - } \quad \text { identifying the } \\
\text { demands of } \\
\text { Indigenous } \\
\text { peoples. } \\
\text { being open to the } \\
\text { world. }\end{array}$ & $\begin{array}{l}\text { Teachers know about: } \\
\text { - Indigenous and } \\
\text { dominant } \\
\text { languages. } \\
\text { - cognitive and } \\
\text { psychological child } \\
\text { development. }\end{array}$ \\
\hline
\end{tabular}




\begin{tabular}{|c|c|c|}
\hline $\begin{array}{l}\text { - } \quad \text { improve according to } \\
\text { the guidelines of that } \\
\text { research. } \\
\text { - } \quad \text { analyze the world } \\
\text { from different } \\
\text { perspectives. } \\
\text { create new } \\
\text { relationships } \\
\text { between written and } \\
\text { oral languages. } \\
\text { manage conflict. } \\
\text { - collaborate with } \\
\text { Indigenous } \\
\text { communities. } \\
\text { use student } \\
\text { knowledge and } \\
\text { experiences in the } \\
\text { classrooms. } \\
\text { interact with people } \\
\text { who are similar and } \\
\text { different to them. } \\
\text { work in teams with } \\
\text { school members. }\end{array}$ & $\begin{array}{l}\text { - } \quad \text { being tolerant. } \\
\text { taking an active role } \\
\text { in teaching the } \\
\text { benefits of the IBE } \\
\text { program. } \\
\text { possessing critical } \\
\text { awareness of the } \\
\text { hegemonic } \\
\text { approach of IBE } \\
\text { schools. } \\
\text { recognizing the } \\
\text { importance of } \\
\text { family and } \\
\text { community in } \\
\text { education. } \\
\text { valuing students' } \\
\text { existing knowledge. }\end{array}$ & $\begin{array}{ll}\text { - } & \text { interaction of } \\
\text { cultures in IBE } \\
\text { schools. } \\
\text { - } \text { Indigenous } \\
\text { worldviews and } \\
\text { epistemologies. } \\
\text { - } \quad \text { history and } \\
\text { geography from an } \\
\text { Indigenous } \\
\text { perspective. } \\
\text { - } \quad \text { intercultural } \\
\text { communication. } \\
\text { intercultural } \\
\text { pedagogies. } \\
\text { - } \quad \text { language laws and } \\
\text { policies, particularly } \\
\text { IBE policies. } \\
\text { - perceptions of } \\
\text { Indigenous } \\
\text { linguistics. } \\
\text { the definition of } \\
\text { culture. } \\
\text { moral development } \\
\text { in multicultural } \\
\text { societies. }\end{array}$ \\
\hline
\end{tabular}

Although these proposals aim to advance the discussion of what educators should know to teach in IBE schools, the studies are based mostly on theoretical discussions. As such, they fail to incorporate the experiences and knowledge that teachers gain during their daily practices.

\section{Sociocultural Perspectives on Second Language Teacher Education}

The learning of second language teachers, when viewed from a sociocultural perspective, depends on the specific social activities in which they engage (Johnson, 2006). Teachers' prior experiences, their interpretations, opinions, and beliefs, and their daily activities are remarkably significant in shaping how teachers learn to teach. The sociocultural perspective on second language teacher education is used in this study to capture the complexities of what inservice teachers think about how to learn to teach for IBE settings; this approach is particularly relevant for the Chilean context, since, as we mentioned, most of the teachers who work in IBE schools did not receive any preparation specifically related to IBE.

We identified four core aspects of the sociocultural approach of second language teacher education that are relevant to this study: experiential knowledge, human mediation, social and political factors, and teacher identity. From a 
sociocultural perspective, Battiste (2002) accounts for teachers' learning via their experiential knowledge and what they learn during their practice of teaching as well as during their teacher education program. Following the argument that teachers' "informal social and professional networks, including their own classrooms, can function as powerful sites for professional learning" (Johnson, 2006, p. 96), experiential knowledge is critical to becoming an "expert" in teaching (Lave \& Wenger, 1991).

Studies in different countries have found that teachers draw from their experiential knowledge, gained from communities during their training, to enact their daily teaching practices (Belgarde, Mitchell \& Arquero, 2002; Educación Intercultural Bilingüe Amazonia, UNICEF \& Finland, 2012; Zeichner \& Melnick, 1996). In the context of teacher training for schools with native people in Alaska, Zeichner and Melnick (1996) found that experience-based interactions may help student-teachers to recognize diversity within Indigenous and non-Indigenous communities; it may also help teachers avoid seeing language and culture as static and homogenous.

Second, the sociocultural approach provides insights into the role that human mediation plays in teacher learning via the assumption that people mediate and are mediated by the social relationships they have with others (Donato, 2000; Johnson, 2006; Rogoff, 1995). In other words, teaching and learning occur as dialogic mediation, meaning that they involve contributions and discoveries by learners, peers, and "expert" collaborators (Gonzalez, Moll \& Amanti, 2005; Johnson, 2006; Lantolf, 2000). From this point of view, teachers also become active producers of knowledge for their own means and for their own instructional contexts, such as IBE schools (Johnson, 2006; Johnson \& Golombek, 2003).

Third, a sociocultural approach emphasizes the importance of including political and social factors in teacher training programs. Regarding the role these macro-structures play in teacher training programs, Johnson (2006) argues that individual mental functioning does not exist separately from the cultural, institutional, and historical situations in which it occurs. From this stance, in order to fully understand the activities that teachers engage in, it is essential to understand the larger social, cultural, and historical macro-structures that form those activities. Later in this article we provide a brief description of some of the major structures in the Chilean context.

Relevant studies have noted positive outcomes when language preparation for teachers focuses on integration of the sociopolitical dimension of learning and teaching a language (Lucas \& Grinberg, 2008). Delany-Barmann's work in Bolivia (2010) and Veintie and Holm's work in Ecuador (2010) highlighted this necessity. Teachers' awareness of the political and social context to learning and teaching a language is crucial, particularly in IBE schools in Región Metropolitana in Chile, which has historically considered itself a culturally "white" and homogeneous society even though nearly $34 \%$ of Mapuche people live in this area (INE, 2002). 
Additionally, the Mapuche people in this area suffer constant threats of homogenization in schools, are labeled as "terrorists" and thrown in jail for demanding their right to own land, and continue to fight for the right to speak their own language. Indeed, even though the discussions surrounding urban Mapuche have gained increasing attention over the last decade, the Mapuche in Santiago have historically been invisible to the rest of urban society (Ojeda, 2009). When they are not ignored, Mapuche are made visible through stereotypes as "poor," "violent," and "uncivilized," images that the media reinforce with pictures of land occupations in the South and armed battles with landowners near the villages (Abarca, 2005; Aravena 2007).

The fourth relevant aspect of a sociocultural approach to this case study is how teachers' identity relates to teaching a second language (e.g., Duff \& Uchida, 1997; Morgan, 2004; Pavlenko, 2003; Varghese, 2000). From this line of thinking, teacher identity is a crucial component in developing successful means to teach language. As Varghese, Morgan, Johnson, and Johnson (2005) stated, "In order to understand teachers, we need to have a clearer sense of who they are: the professional, cultural, political, and individual identities which they claim or which are assigned to them" (p. 22). These authors also note that an important aspect of teachers' identities is that identity "is not context-free," but is crucially related to social, cultural, and political context-interlocutors, institutional settings, and so on" (Varghese et al., 2005, p. 23). This argument highlights the significance of the relationship between assigned identity, which is the identity imposed by others, and claimed identity, which is the identity or identities one acknowledges or claims for oneself (Buzzelli \& Johnston, 2002).

With this framing in mind, we turn now to the specific context in which this study took place, paying special attention to the historical and social aspects of Chilean history and society that impacted the work of the preschool teacher participants in IBE schools.

\section{IBE in Context: Intercultural and Bilingual Education and Preschool in Chile}

Though it is beyond the scope of this study to provide a complete history of Indigenous groups in Chile, there are some significant events that are important to contextualize the IBE program. Although Chile has a proportionally smaller Indigenous population than other neighboring countries (e.g., Bolivia, Ecuador, and Peru), it is home to one of the four largest Indigenous language groups on the continent (McEwan, 2008). In total, there are 1,060,786 Indigenous individuals in Chile, or $6.6 \%$ of the total population-of which, $87.2 \%$ identify themselves as Mapuche, which makes up the largest Indigenous group in the country (Ministerio de Planificación, 2006).

As a result of Indigenous demands and the democratization of Chilean society, the Chilean National Congress passed the Indigenous Law 19.253 in 1993 
that established rules for the protection, promotion, and development of its Indigenous populations (Turra et al., 2013). The same year, the National Corporation of Indigenous Development (Corporación Nacional de Desarrollo Indígena, CONADI) was created. After the promulgation of the Indigenous Law, the Ministry of Education established the Intercultural and Bilingual Education Program (1996) within the Rural and Elementary Education Program (2000) to improve students' achievement by strengthening the ethnic identity of girls and boys attending primary schools located in contexts of cultural and linguistic diversity (Ministerio de Educación, 2005; Turra et al., 2013).

Despite the enactment of the Indigenous Law in 1993, only with the ratification of the Convention 169 of the International Labor Organization in 2009 did the Chilean government begin to implement viable measures to protect and increase the use of Indigenous languages. In accordance with this agreement, the Ministry of Education included Indigenous language classes (known as Sector de Lengua Indígena [Areas of Indigenous Languages]) as part of the national mandatory objectives for Elementary and Middle Education. This regulation mandated that, beginning in 2012, all schools with an enrollment of $20 \%$ or more Indigenous students must include an Indigenous language in their curriculum (Loncon et al., 2011). Additionally, the National Corporation of Indigenous Development and the National Association of Preschools (known as JUNIJI, the Junta Nacional de Jardines Infantiles) established an intercultural approach in Chile's preschool system to strengthen cultural identity and sense of belonging of Indigenous communities, enhance the educational role of families and communities, promote native languages in Indigenous children, and provide culturally relevant food to Indigenous children (Bustos et al., 2014).

These educational reforms have created a significant need in Chile for teachers who are specially trained to teach the IBE curriculum. However, despite these reforms, few efforts have been made to prepare teachers for the unique aspects of IBE preschools in urban settings, and little is known about their experiences. This absence of research prompted our examination of the topic and informed our study, which we descrlBE in the following section.

\section{Design and Method}

In order to investigate the research questions above, we used a qualitative case-study methodology (Merriam, 2009; Wolcott, 1997; Yin, 2009) which allowed us to conduct an intensive investigation of one or more instances of the same phenomena. This case is comprised of four educators at one IBE preschool in Región Metropolitana, Chile. Using criterion sampling (Merriam, 2009), we chose a preschool from which we would then select teachers to include as participants. We determined that this preschool was a suitable setting for this study since it was a public preschool in Región Metropolitana (the capital region of Chile), where 
Mapudungun was already being taught as a second language, in accordance with the guidelines of the Ministry of Education. The preschool has 146 children, 8 preschool teachers and 20 preschool teacher assistants. The preschool has implemented an intercultural curriculum based on Indigenous worldviews and Indigenous children socialization. Although Mapudungun is the focus of their language revitalization efforts, the school's members also work to include Aymara, Rapanui, and the culture of immigrant children in the preschool. In addition, this preschool was situated in a district that contained a high population of Mapuche people, as well as high rates of poverty and low rates of completed formal education. Considering the significant forced migration of Indigenous groups from rural areas to major cities (Aravena, 2007; López, 2008; Ortiz, 2008), it was crucial for us to conduct research that examined the challenges and opportunities related to urban migration.

The teachers from this preschool were selected for this study based on two criteria: their ethnicity (Mapuche or non-Mapuche) and their role in the school (teacher or teacher assistant). ${ }^{4}$ We sought an even number of Mapuche and nonMapuche participants, as well as participants who had different roles in the preschool. There were no Mapuche teachers in this preschool, and therefore, it was not possible to select one. We first selected one non-Mapuche teacher and one Mapuche teacher assistant, and we then chose two administrators for participation in this study, selecting the principal and preschool coordinator because they were responsible for making decisions about teacher training and support. Also, we decided to include these two professionals in this study because in 2012 the preschool underwent a restructuring process, after which two teachers were promoted to their current roles as principal and coordinator. ${ }^{5} \mathrm{~A}$ complete list of participants is provided in Table $2:^{6}$

Table 2

Participants

\begin{tabular}{|c|c|c|c|c|}
\hline Educator & Ethnicity & Role & Degree level & $\begin{array}{c}\text { Teaching } \\
\text { experience }\end{array}$ \\
\hline Marcela & Mapuche & Principal & Preschool teacher & 20 years \\
Antonia & Non-Mapuche & Coordinator & Preschool teacher & 13 years \\
Carolina & Non-Mapuche & Teacher & Preschool teacher & 11 years \\
Laura & Mapuche & Teacher & Preschool teacher & 3 years \\
& & Assistant & assistant & \\
& & & & \\
\hline
\end{tabular}

Data for this study was primarily collected during February and March of 2013 through eight in-depth, semi-structured interviews (two interviews with each participant), which each lasted approximately an hour. Prior to data collection, the 
principal researcher spent six months doing fieldwork to establish context for the study and criteria for sampling. The same researcher conducted all the interviews, and because of the length, each interview was arranged to take place at different times. The interviews were conducted using Skype and recorded with a recording device. There are both affordances and constraints when conducting interviews via Skype. Skype offers the practical benefits of scheduling flexibility and ensures that both parties are in a familiar and safe environment, such as their own home (Hanna, 2012). However, one potential disadvantage is the loss of non-verbal communication and cues, which can be important to note during interviews. All interviews were conducted in Spanish, which was the first language of both the participants and the researcher conducting the interviews. Data was also collected via email in order to address specific issues that arose during data review and analysis. In addition, public policy documents regarding intercultural and bilingual education in Chile from the Internet were collected, such as Indigenous Law 19.253, Decreto 280, Decreto 2960, and Convenio 169 (see Table 3). These documents were collected in order to help us better understand the policy setting that teachers were located in.

Table 3

Summary of Policy Documents Regarding IBE

\begin{tabular}{|c|c|c|c|}
\hline Document & Author & Main purpose & Year \\
\hline $\begin{array}{c}\text { Indigenous } \\
\text { Law, 19.253 }\end{array}$ & $\begin{array}{c}\text { Chilean } \\
\text { Government }\end{array}$ & $\begin{array}{c}\text { Established norms about the protection, } \\
\text { promotion, and development of Indigenous } \\
\text { peoples and created the National Corporation of } \\
\text { Indigenous Development. }\end{array}$ & 1993 \\
\hline Decreto 280 & $\begin{array}{c}\text { Ministry of } \\
\text { Education }\end{array}$ & $\begin{array}{c}\text { Incorporated the Indigenous Language course into } \\
\text { the national curriculum from 1st to 8th grade }\end{array}$ & 2010 \\
\hline Decreto 2960 & $\begin{array}{c}\text { Ministry of } \\
\text { Education } \\
\text { Convenio 169 } \\
\text { Government } \\
\text { International } \\
\text { Labor } \\
\text { Organization) }\end{array}$ & $\begin{array}{c}\text { Approved programs from 1st to 6th grade to teach } \\
\text { Indigenous languages in schools }\end{array}$ & 2012 \\
\hline & $\begin{array}{c}\text { Recognized the rights of Indigenous Peoples to } \\
\text { control their own institutions, their own lives, and } \\
\text { economic development, and to strengthen their } \\
\text { identities, languages and religions. }\end{array}$ & 2009 \\
\hline
\end{tabular}

Iterative data analysis took place throughout the course of data collection, and then formally post-data collection from April through June 2013. We began by reading teachers' responses to questions about their preparation for IBE 
preschools, and then identified themes through open coding (both individually and as a team) (Miles \& Huberman, 1994). Then we developed thematic documents and created a code book using qualitative analysis software (Dedoose) for instances where participants talked about teachers' needs regarding their preparation to teach in IBE schools. Dedoose is a web-based qualitative/mixed methods research software; we chose to work with Dedoose because this software allows different members to have access to the analysis at different times and places. We paid close attention to validity and reliability throughout this study through member checks and peer review (Merriam, 2009). Two Mapuche colleagues and friends generously helped in the peer review process by providing feedback in the analytical stage about the coding and findings. In addition, the main findings were presented to the school members at a final meeting.

This study, like any, has limitations. While the focus on the Chilean context is a strength of this study and contributes much needed scholarship in the field of IBE, this case study is limited in the amount of data examined. This study did not include observational data about classroom practices, due to distance constraints between Chile and the researchers' physical locations during this study. Therefore, this study cannot offer interpretation of actual classroom instruction. In future work, it would also be important to include additional participants from other IBE preschools in order to better understand the implications of this policy in different teaching contexts. In the following section, we present findings related to IBE preschool educators' perceptions of their preparation to teach in urban settings in Región Metropolitana.

\section{Findings and Discussion}

Drawing on the conceptual framework presented above, as well as the main research questions that prompted this study, teachers' responses were placed into categories, and these categories were organized into three groups: (a) their perceptions of their needs for IBE preparation; (b) how their educational experiences supported their ability to teach an Indigenous language; and (c) the challenges they faced in daily practices in IBE preschools.

\section{Teachers' Perceptions of Their Needs to Teach Mapudungun in Preschool Education}

Across the interviews, three categories emerged with regard to the question of teachers' perceptions of their needs in their preparation to teach an Indigenous language in urban IBE preschools. By the end of their training, teachers felt they should have (a) known more about Mapuche culture and knowledge; (b) gained 
experiential knowledge; and (c) gained a sociopolitical perspective of the Mapuche people.

Mapuche culture and knowledge. Both the administrators and teachers identified Mapuche culture and knowledge as an important component of teacher preparation. Antonia, the non-Mapuche coordinator, suggested that before teachers learned to speak Mapudungun, they should learn the "Indigenous worldview," which for her included "customs" and "the meaning of life." Here, Antonia distinguished between linguistic skills and Mapuche cultural knowledge, suggesting that learning Indigenous worldviews is essential before learning Mapuche words. However, Antonia and the other educators also saw the value of learning the language, in particular, new vocabulary.

The relevance of Mapuche knowledge over linguistic knowledge can be explained by the fact that the preschool used a life experience approach to teaching; that is, everything was learned in context. Carolina, the non-Mapuche teacher, reflected on how she applied her knowledge of Mapudungun that she learned from the Indigenous Language and Culture Educator:7 "We do not apply it, we live it." According to her, the big challenge, then, was that most teachers did not know enough about the traditions and culture to properly use Mapudungun. Geographically, these teachers were in an urban setting where Mapudungun was not spoken daily, and it was likely that the non-Mapuche educators, such as Carolina, had never even heard Mapudungun being spoken.

In addition, regarding the content of teacher training, Carolina also specified that teachers should go beyond learning about Mapuche customs and traditions to learning the native communication patterns between Mapuche parents and children. This opinion reflects the current problem amongst teachers in Latin American IBE programs, that is, their deficient understanding regarding Indigenous communication and early socialization patterns (Godenzzi, 2006). Carolina's suggestion echoes the demands of the Mapuche people to include Mapuche ways of learning, rather than just Mapuche words, phrases, songs, or ceremonies (Ortiz, 2008). Additionally, Laura, the Mapuche teacher assistant, asked, "How [could] we ... use Mapudungun to preserve the culture if we do not know the culture?" Both Carolina's and Laura's opinions reveal their understanding that teaching Mapudungun is a mechanism for the preservation of Mapuche culture.

Experiential knowledge. Experiencing Mapudungun and Mapuche people in "real life" was identified as a central factor to improve the preparation of future educators in IBE schools. For example, Marcela, the Mapuche principal, firmly indicated that teachers should "visit organizations," "meet people from other places," and attend celebrations, rather than learn "only the theoretical content... 
[taught] in universities." Without these "direct interaction[s]," Marcela said that teachers would not be able to "experience" and "feel" Mapuche culture.

Laura, the Mapuche teacher assistant, shared the same opinion, emphasizing the link between experiential knowledge and visiting IBE preschools: "[seeing] how people work elsewhere...would help us." She also distinguished between interculturalism and "folklore," stating the only way to see the difference is "to live with cultures" and "see things." It is noteworthy that although both Marcela and Laura stressed the significance of first-hand experiences, Marcela referred to visiting, interacting, and spending time with Mapuche communities outside the school, while Laura referred to visiting other preschools.

It is important to mention that Marcela, the Mapuche principal, frequently mentioned the relevance of experiential knowledge during her interview. She descrlBEd her personal experiences, including how her Mapuche father encouraged her to learn the Mapuche culture by taking her to ceremonies, rituals, and meetings when she was a child. In contrast, the other Mapuche educator, Laura, mentioned that her parents did not teach her Mapudungun or its culture because of their own experiences of discrimination as Mapuche. Perhaps because of the lack of experiences with her own native culture, Laura expressed the value of experiential knowledge in teacher preparation. In short, both Mapuche educators used personal stories as evidence to support the need for "real life" interactions between Mapuche communities and teachers in IBE schools.

These findings are aligned with recent studies that propose that educators in IBE settings should receive both theoretical and practical preparation (Kuper \& Valiente, n.d.). In fact, experiential knowledge (conocimiento vivencial) is an important component in teacher programs for IBE in Peru, Bolivia, and Ecuador (Educación Intercultural Bilingüe Amazonía, UNICEF, \& Finland, 2012; Quintero \& Crespo, 2006), where opportunities exist for pre-service teachers to gain rich experiences with Indigenous communities. Even though the experiential approach has been implemented in neighboring countries, it is almost nonexistent in Chile, which makes Marcela's and Laura's proposals particularly noteworthy. Currently, no teacher education program in Chile-neither for IBE or mainstream schoolsconnects pre-service teachers with first-hand experiences with Mapuche communities. $^{8}$

It is also worth noting that only the Mapuche educators interviewed in this study explicitly talked about the value of experiential knowledge in teacher preparation and also about the gap between theory and practice to teach Mapuche culture and language. In contrast, the two non-Mapuche educators emphasized the importance of what they considered "real-life" interactions with Mapuche culture, specifically, through their connection at the school with Mapuche organizations and Indigenous Language and Culture Educators; however, they did not identify the value of immersion in Mapuche communities outside the school. As discussed later, this perspective may stem from political sources or from lack of knowledge about the Mapuche people in Región Metropolitana. 
Sociopolitical perspective. In addition to experiential learning, our interviewees revealed the significance of teachers' learning the sociocultural context of Mapudungun, including the historical and political situations in which this learning occurs. Laura, the Mapuche teacher assistant, said that future teachers should understand "the whys" of Mapuche culture or, in other words, the history of the Mapuche people. Similarly, Marcela, the Mapuche principal, said that educators must recognize that "there is no one culture" in Chile; instead, it is "a multicultural country." In her opinion, learning about other cultures would help teachers "open [their] minds and [their] hearts." Importantly, in this comment Marcela not only historicized learning and teaching Mapudungun, but also connected teacher preparation to acquiring a diverse understanding of the Chilean society to the active role of educators.

What is interesting about Marcela's perceptions is that there are different stages in acquiring this diverse knowledge: first, being aware of Chile's multicultural nature; second, opening one's mind and heart; and third, acting to dehomogenize the country through daily practices such as teaching Mapuche culture and language. In this way, Marcela's comment reflects the concept of educators as political actors, which is a role that has been identified as a significant aspect of teacher training for IBE schools (López, 1997; Trapnell, 2003, 2011). However, the other three educators interviewed in this study did not share this same notion of teachers. For example, Carolina, the non-Mapuche teacher, said they did not regularly address the topic of Mapuche demands; instead, to emphasize her political neutrality, she said, the Mapuche people "came to Santiago to avoid those conflicts."

Still, despite the difference on this point, it is worth mentioning that for all four participants in this study, interview discussions of the sociocultural perspective mainly focused on the multicultural nature of the country and the history of Mapuche people rather than economic issues. For example, the preschool used in this study is located in one of the poorest cities in Región Metropolitana, yet none of the educators addressed socioeconomic conditions related to this urban environment.

\section{Challenges Faced by Teachers in IBE Preschools}

Regarding the second research question, this study showed that the challenges that teachers face in teaching Mapudungun in IBE preschools fall into two categories: (a) lack of understanding of interculturality and (b) identity struggles.

Interculturality. In interviews, all participants addressed the challenge of teaching in Chile, which lacks a clear notion of interculturality and considers itself 
homogenous in spite of its large Indigenous population. For example, Laura, the Mapuche teacher assistant, said, "Interculturality in Chile is in its infancy." A recent report from the Chilean Ministry of Education (2011) echoed this opinion. In fact, the lack of precision of this notion was one catalyst for the implementation of the IBE program (Programa de Educación Intercultural Bilingüe, Ministerio de Educación \& UNICEF, 2012). A relevant study of IBE-specific teacher education in Peru, Bolivia, and Ecuador (Quintero \& Crespo, 2006) found that only a few of these programs clearly define the notion of interculturality.

Identity. A salient theme for both Mapuche and non-Mapuche educators was their identity struggle in teaching Mapudungun. Antonia, the non-Mapuche coordinator, descrlBEd herself as a huinca, the Mapuche word for foreigner or nonnative person and said: "I felt that I should not be doing that. As non-Mapuche, I did not have enough knowledge [about Mapudungun]" to teach it." "But," she added, "I have been growing and learning, and because I respect and value [their culture] I can also be part of this [teaching]."

This comment was particularly significant because the word huinca has a negative connotation amongst Mapuche as meaning someone who does not know Mapuche culture, knowledge, and language. In other words, a huinca is an outsider. The fact that Antonia used this word to descrlBE herself showed her own identity struggle, both the one she developed and the identity assigned to her. Similarly, Carolina, the non-Mapuche teacher, felt she was not the right person to teach Mapudungun, saying, "I think they [Mapuche communities] would prefer me to be Mapuche." Then she compared her relationship with them, to their relationship with Marcela: "They all have good relationship with Marcela since she's Mapuche."

Even the Mapuche teacher, Laura, faced the challenge of identity; however, she understood it as a "rich process" in which she learned about her culture, which was "where she belonged." Prior to her work in an IBE school, it was "hard" for her to identify herself as Mapuche, but now she could say, "I am Mapuche."

Relevant literature documents similar experiences of non-Mapuche teachers in Chilean rural schools as well (Relmuan, 2001). This widespread feeling of inadequacy has prompted non-Mapuche teachers to request Mapudungun classes in their teaching programs and to critique the fact that most Mapudungun classes are designed for Mapuche teachers. To help non-Mapuche second language teachers overcome these identity challenges, a number of researchers suggest a reconceptualization of second language teaching to include a newer understanding of language and identity. For example, Gee (2004) points out that languages enact distinctive identities and activities that are highly relevant in professional settings. In the same vein, Pavlenko (2003) descrlBEs the process of acquiring new linguistic, social, and cultural practices as self-translation. 
In summary, interview data suggest the need to view language not only as a structural property or, in other words, exclusively based on grammar or vocabulary, but also as an influence on teachers' identities. It is worth noting that García (2008) found that peer-discussion regarding students' own identities was one of the most positive experiences during a master program for IBE.

\section{Educators' Experiences Teaching in IBE Preschools}

The supportive and helpful experiences that prepared teachers to learn and teach fall into three categories: (a) interactions with Mapuche communities; (b) interactions with Indigenous Language and Culture Educators; and (c) interactions with the school's principal.

Interactions with Mapuche communities. Throughout the interviews, the four educators frequently referred to the preschool's partnership with an Indigenous organization as an essential factor in their ability to teach Mapudungun. For example, Antonia, the non-Mapuche coordinator, said she felt "more support and guidance" on hosting authentic celebrations because of the partnership with a Mapuche organization. Similarly, Laura, the Mapuche teacher assistant, felt supported in learning Mapudungun, saying the Mapuche communities teach "how things are named," but also about ceremonies. Additionally, Carolina, the nonMapuche teacher said she felt more confident in teaching Mapudungun because of her participation in Mapuche activities; she relayed this opinion by stating that non-Mapuche people, which she referred to by using the word huincas, could teach Mapudungun in IBE schools.

Interactions with the Indigenous Language and Culture of Educator. Known as Indigenous Language and Culture Educators, these Mapuche people teach their native language and culture in IBE preschools. The important impact these educators have on teachers' education was a salient theme of this study's interviews. For instance, Marcela, the Mapuche principal, said this educator primarily "made connections" between Mapuche and mainstream culture, "talking to children, singing, participating in celebrations, guiding families...during celebrations." In addition, this educator's knowledge of Mapuche influence in popular culture (in this case, a fusion band that mixed traditional Mapuche music with rap) made her a bridge between mainstream and Indigenous cultures. Similarly, Antonia, the non-Mapuche coordinator, valued that the Indigenous Language and Culture Educator spoke Mapudungun all day and shared Mapuche culture through dances, music, and poetry. Besides language, Carolina, the nonMapuche teacher, valued how the Indigenous Language and Culture Educator explained about cultural practices such as "the use of herbs," and "how they made their own shampoo." In these comments, the educators seemed to value learning 
Mapudungun in everyday situations, as well as the social and cultural aspects of Mapudungun.

Interactions with the principal. Interestingly, the coordinator and two teachers spoke of the importance of their interaction with the principal, both in general and in terms of their professional development. They all agreed that having a Mapuche principal allowed them to connect with Indigenous communities, which they considered valuable. For example, when Carolina, the non-Mapuche teacher, first came to the preschool, she said, "Marcela helped me a lot... [she] trained me, taught me." In contrast, when she graduated from her education program, Carolina felt "very ignorant" about teaching Mapudungun, and thought "spending one week with Mapuche people" would give her enough information to teach Mapuche culture. She realized now "that this was not so."

For Antonia, the non-Mapuche coordinator, the importance of the principal's heritage had a personal basis: Marcela had a Mapuche father and a non-Mapuche mother and, therefore, could navigate both worlds with tolerance. In general, the three educators considered the principal as an "expert" in IBE classrooms and during Mapuche activities and projects, and as such, valued her guidance.

\section{Conclusion}

In this study, we explored educators' perceptions of their needs regarding preparation to teach in IBE preschools. Regarding preparation to teach Mapudungun, findings show that teachers need more knowledge about Mapuche culture, including sociopolitical aspects of Mapudungun, as well as first-hand experiences with Mapuche communities. In interviews with all four participants, knowledge of Mapuche culture was considered critical since it would promote understanding of the Mapuche ways of learning and teaching, as well as the communication patterns between parents and children.

This finding is relevant considering that existing literature considers language as priority; in fact, training courses for teachers that focused on Mapuche culture have been criticized (Red EIB Chile, 2011). Based on data from this case study, we believe that a broader definition of learning and teaching a language, which includes both linguistic and sociocultural elements, is necessary in order to adequately prepare teachers for IBE preschools.

In addition, incorporating social, cultural, political, and historical aspects of Mapuche culture into teacher preparation was seen as valuable, particularly by the Mapuche educators. Recognizing Chile's multicultural nature and understanding the historical conditions of its Indigenous people is especially relevant because Chile sees itself as homogeneous nation (Williamson, Pérez, Collia, Modesto, \& Raín, 2012); this notion presents a challenge to IBE programs, which, according 
to Mapuche educators, can be overcome in teacher education by moving beyond theory into interaction with native peoples.

On this note, the four educators highly valued experiential knowledge in teacher education and professional development, and explicitly said that future teachers should interact with Mapuche communities, Indigenous Language and Culture Educators, other IBE preschools, and experts and colleagues. For these educators, the experiential knowledge acquired in these situations was essential for overcoming some of the challenges in teaching Mapudungun. These experiences were also recognized as key in understanding the notion of interculturality in Chilean society. They were also significant ways for these educators to overcome challenges on identity struggles.

Through their interviews, the educators presented themselves as active learners, meaning they conceived their learning as strongly connected to their classroom practices and their school community. The participants situated their learning in social practices within their schools, and it was distributed across experts and colleagues (Antonia, Carolina, and Laura). They also placed their learning in the macrostructures in which the school is located (Marcela).

In connecting these findings with the IBE policy in Chile, we can conclude that the emphasis on the role of the Indigenous Language and Culture Educators should be accompanied with an emphasis on the inclusion of entire Mapuche communities. In addition, the appreciation of the historical and political dimensions of working with Mapuche people is quite important if we consider that this dimension is absent in current IBE policy. In fact, authors (such as Quintrileo, Yáñez, \& Valenzuela, 2013; Quintriqueo, 2009) have critiqued the IBE policies in Chile for having a functional intercultural perspective. Walsh (2010) descrlBEs that this perspective of interculturalism that attempts to accept, protect, and give spaces for diversity in a given country implies that diversity must function ultimately within the context, limit, and structure of a country's national system. Also, the individual focus of the IBE policy-conceiving that IBE works mainly within each preschool and not among preschools-should be replaced by a more connected and collaborative network that allows teachers to interact in "IBE system" (Williamson, 2012).

\section{Looking Forward: Implications for the Preparation of Teachers for IBE preschools}

In light of these findings, teacher education programs for IBE preschools should incorporate a more complex notion of Indigenous language learning that is linked directly to Mapuche culture and its sociopolitical context and should include the experiential knowledge of teachers in its curriculum. 
The four educators' appreciation of the Indigenous Language and Culture Educator as well as Mapuche organizations supports the inclusion of different actors and experts in IBE training programs. To achieve this, IBE schools should encourage participation of both Mapuche members with cultural expertise, as well as of peers, teachers, and principals who have experience working in IBE preschools. Though professors were seen as resources of knowledge, teacher programs should go beyond academic structures to include first-hand experience in urban Mapuche contexts.

The challenges these educators faced indicate that teacher preparation programs need to address issues regarding teachers' identity and that they also need to clearly acknowledge interculturality-especially within urban Indigenous contexts. Finally, the findings of this study need to be revisited when studies with bigger samples could be conducted and more extensive data on the institutional contexts of the IBE preschools could be added to the data analysis and interpretation. Although we propose potential changes to teacher training programs, the primary purpose of this study was to open a conversation about important and relevant issues. In doing so, we hope to move beyond the current discussion that is focused on what teachers do not know towards a more reflective analysis of teachers' perceptions of their needs to teach in IBE preschools.

\section{Acknowledgments}

This work was supported by the Interdisciplinary Center for Intercultural and Indigenous Studies-ICIIS under Grant CONICYT/FONDAP/15110006. We are grateful for the knowledge and experiences that our participants shared with us during this study, and for the work of the reviewers; all errors are our own.

\section{Notes}

1. The Intercultural and Bilingual Education (IBE) program is the only Chilean formal institution that works for the education of Indigenous children. This program is managed by the State through the Chilean Ministry of Education.

2. It is important to mention that in this study we use the term teacher education to refer to the professional preparation and continuing professional development of teachers. Thus, the terms 'teacher education' and 'teacher preparation' are largely interchangeable in this study.

3. Pre-service refers to the education and experiences that occur in a teacher preparation program, versus in-service, which refers to teachers who have completed the program and are currently teaching. 
4. We use the term teacher assistant, although the term used in Chile is técnico en educación parvularia, which translates directly to mean "technician in preschool education."

5. We refer to the teacher, paraprofessional, principal and coordinator as educators since the participants conceive of themselves and the other actors as educators.

6. All names used in this study are pseudonyms.

7. An Indigenous Language and Culture Educator is a Mapuche person who teaches Mapuche language and culture in the preschool level. In Spanish it is Educador de Lengua y Cultura Indígena.

8. During 2014, a teacher education program in the north of Chile improved its efforts in connecting pre-service teachers with experiences in Aymaras communities. However, no efforts have been documented for teachers' firsthand experiences with Mapuche culture.

\section{References}

Abarca, C. G. (2005). Rupturas y continuidades en la recreación de la cultura mapuche en Santiago de Chile [Ruptures and continuities in the recreation of the Mapuche culture in Santiago de Chile]. La Paz, BO: PINSEIB/PROEIB Andes/Plural Editores.

Abarca, G., Alarcón, S., Huircán, M., Millacura, C., \& Olivares, P. (n.d.). Propuesta de orientaciones metodológicas para elaborar planes y programas para establecimientos que desarrollen educación intercultural bilingüe [Proposal of methodological guidelines for developing plans and programs in intercultural and bilingual institutions]. Retrieved from http://www.forolatino.org

Aravena, A. (2007). Shadows in the big city. Retrieved from http://www.mapuchenation.org/english/html/news/n-130.html

$\mathrm{Au}$, K. H. (2002). Communities of practice: Engagement, imagination, and alignment in research on teacher education. Journal of Teacher Education, 56(3), 222-227. doi: 10.1177/0022487102053003005

Battiste, M. (2002). Indigenous knowledge and pedagogy in First Nations education. A literature review with recommendations. Retrieved from http://www.afn.ca/uploads/files/education/24. 2002 oct marie battiste In digenousknowledgeandpedagogy lit review for min working group.pdf

Belgarde, M. J., Mitchell, R. D., \& Arquero, A. (2002). What do we have to do to create culturally responsive programs?: The challenge of transforming American Indian teacher education. Action in Teacher Education, 24(2), 4254. doi: $10.1080 / 01626620.2002 .10734418$ 
Boyle-Baise, M. (1998). Community service learning for multicultural education: An exploratory study with preservice teachers. Equity \& Excellence in Education, 31(2), 52-60. doi: 10.1080/1066568980310207

Bustos, C., Cariman, A., Díaz, Z., \& Merino, M. (2014). Educación parvularia en escuelas con enfoque intercultural [Preschool education in schools with intercultural approach]. Santiago, Chile: Ministerio de Educación.

Buzzelli, C. A., \& Johnston, B. (2002). The moral dimensions of teaching: Language, power, and culture in classroom interaction. New York, NY: Routledge.

Carihuentro, S. (2007). Saberes que debería incorporar la educación formal en contexto interétnico e intercultural según sabios mapuche [Knowledge that formal education in interethnic and intercultural context should incorporate according to Mapuche wise people] (Unpublished master's thesis). Universidad de Chile, Santiago, Chile.

Catriquir, D. (2014). Desempeño del profesor de Educación Intercultural Bilingüe: Criterios evaluativos desde la voz del lof che [Competence of the Intercultural and Bilingual Education teacher. Evaluative criteria in the voice of lof che]. Polis: Revista De La Universidad Bolivariana, 13(39), 1-19.

Cochran-Smith, M. (2004). Walking the road: Race, diversity, and social justice in teacher education. New York, NY: Teachers College Press.

Delany-Barmann, G. (2010). Teacher education reform and subaltern voices: From política to práctica in Bolivia. Journal of Language, Identity, and Education, 9(3), 180-202. doi: 10.1080/15348458.2010.486276

Donato, R. (2000). Sociocultural contributions to understanding the foreign and second language classroom. In J. Lantof (Ed.), Sociocultural theory and second language learning (pp. 27-50). New York, NY: Oxford University Press.

Duff, P. A., \& Uchida, Y. (1997). The negotiation of teachers' sociocultural identities and practices in postsecondary EFL classrooms. TESOL Quarterly, 31, 451-486.

Educación Intercultural Bilingüe Amazonía, UNICEF and Finland (2012). Formación docente inicial y continua. Trabajando por la calidad de una educación con identidad propia [Initial teacher education and teacher development. Working for a quality education with own identity]. Retrieved from http://www.unicef.org/ecuador/formacion docente.pdf

Fernández, F. (2005). El currículum en la educación intercultural bilingüe: Algunas reflexiones acerca de la diversidad cultural en la educación [The curriculum in bilingual intercultural education: Some reflections on cultural diversity in education]. Cuadernos Interculturales, 3(4), 7-25.

García, M. E. (2008). A study of the impact of the PROEIB Andes/Un estudio del 
impacto del PROEIB Andes. Unpublished report. Bilingual report written for the Program for Training in Intercultural Bilingual Education for Andean Countries, Cochabamba, Bolivia.

Gay, G. (2002). Preparing for culturally responsive teaching. Journal of Teacher Education, 53(2), 106-116.

Gay, G. (2010). Culturally responsive teaching: Theory, research, and practice. New York, NY: Teachers College Press.

Gee, J. P. (2004). Learning language as a matter of learning social languages within discourses. In M. Hawkins (Ed.), Language Learning and Teacher Education (pp. 13-32). Buffalo, NY: Multilingual Matters.

Godenzzi, C. (2006). The discourses of diversity: Language, ethnicity, and interculturality in Latin America. In D. Sommer (Ed.), Cultural agency in the Americas (pp. 146-166). Durham, NC: Duke University Press.

Gonzalez, N., Moll, L. C., \& Amanti, C. (Eds.). (2005). Funds of knowledge: Theorizing practices in households, communities, and classrooms. Mahwah, NJ: Lawrence Erlbaum Associates.

Hanna, P. (2012). Using internet technologies (such as Skype) as a research medium: A research note. Qualitative Research, 12(2), 239-242.

Hernández, A. (2007). La formación docente para la educación intercultural bilingüe en Chile [Teacher education for intercultural bilingual education in Chile]. In R. Cuenca, \& V. Zavala (Eds.), Nuevos maestros para América Latina [New teachers for Latin America] (pp. 97-122). Madrid, ES: Ediciones Morata.

Ibáñez, N. (2015). La tríada cultural-contextual: Una oportunidad para asegurar la pertinencia cultural en la implementación de la educación intercultural [Cultural - contextual triad: An opportunity to ensure cultural relevance in the implementation of intercultural education] EstudiosPedagógicos XLI, 1, 323-335. Retrieved from http://www.scielo.cl/scielo.php?pid=S071807052015000100019\&script=sci_arttext

Instituto Nacional de Estadísticas (INE). (2002). Censo 2002: Síntesis de Resultados. Retrieved from http://www.ine.cl/cd2002/sintesiscensal.pdf

Ipiña Melgar, E. (1997). Condiciones y perfil del docente de educación intercultural bilingüe [Teacher conditions and profile for intercultural and bilingual education]. Revista IBEroamericana de Educación, 13, 99-109.

Johnson, K. E. (2006). The sociocultural turn and its challenges for second language teacher education. TESOL Quarterly, 40(1), 235-257. doi: $10.2307 / 40264518$

Johnson, K. E., \& Golombek, P. R. (2003). "Seeing" teacher learning. TESOL Quarterly, 37(4), 729-737. doi: 10.2307/3588221 
Kuper, W., \& Valiente, T. (n.d.). Formación docente en educación bilingüe intercultural en el marco de la modernización [Teacher training in intercultural bilingual education as part of the modernization]. Retrieved from http://www.red-ler.org/formacion_dointercultural.pdf

Lantolf, J. P. (2000). Introducing sociocultural theory. In J. Lantolf (Ed.), Sociocultural theory and second language learning (pp. 1-26). Oxford, UK: Oxford University Press.

Lave, J., \& Wenger, E. (1991). Situated learning: Legitimate peripheral participation. New York, NY: Cambridge University Press.

Lewis, C., Enciso, P., \& Moje, E. (2007). Introduction: Reframing sociocultural research on literacy. In C. Lewis, P. Enciso, \& E. Moje (Eds.), Reframing sociocultural research on literacy: Identity, agency and power (pp. 1-14). Mahwah, NJ: Lawrence Erlbaum Associates.

Loncon, E., Ministerio de Educación, \& Programa de Educación Intercultural Bilingüe (2011). Programa de estudio primer año básico sector lengua indígena mapuzugun [Curriculum of first elementary level for indigeneous language Mapuzungun]. Retrieved from http://www.mineduc.cl/usuarios/ intercultural/doc/201103311112050.ProgMapuzugun_1basicoFinal.pdf

López, L. E. (1997). La diversidad étnica, cultural y lingüística latinoamericana y los recursos humanos que la educación requiere [Ethnic, cultural and linguistic diversity in Latin America and the human resources that education requires]. Revista Iberoamericana de Educación, 13, 47-98.

López, E. 2008. Top-down and bottom up: Counterpoised vision of Bilingual Intercultural Education in Latin America. In N. Hornberger (Ed.), Can schools save Indigenous languages? Policy and practice on four continents (pp. 42-65). Basingstoke, UK: Palgrave Macmillan.

Lucas, T., \& Grinberg, J. (2008). Responding to the linguistic reality of mainstream classrooms. In M. Cochran-Smith, S. Feiam-Nemser, \& D. J. McIntyre (Eds.), Handbook of research on teacher education: Enduring questions in changing context (3rd ed., pp. 606-636). New York, NY: Routledge.

McEwan, P. J. (2008). Can schools reduce the Indigenous test score gap? Evidence from Chile. Journal of Development Studies, 44(10), 1506-1530.

Merriam, S. B. (2009). Qualitative research: A guide to design and implementation. San Francisco, CA: Jossey-Bass.

Miles, M., \& Huberman, A. M. (1994). Qualitative data analysis: An expanded sourcebook (2nd ed.). Thousand Oaks, CA: Sage.

Ministerio de Educación (2005). Orientaciones Programa de Educación Intercultural Bilingüe. [Orientations for Intercultural and Bilingual Education Program]. Retrieved from http://www.peib.cl/link.exe/Documentos/ 
?procesar $=1 \&$ texto $=$ orientaciones $\&$ ano $=$ Todos $\&$ tipo $=$ Todos $\&$ buscar $=$ Busc ar

Ministerio de Educación (2011). Estudio sobre la implementación de la educación intercultural bilingüe [Study on the implementation of bilingual intercultural education]. Retrieved from http://www.mineduc.cl/ usuarios/intercultural/ doc/201111041303130.Estudio_PEIB.pdf

Ministerio de Planificación (2006). Presentación de Resultados de la Encuesta de Caracterización Socioeconómica Nacional 2006, Pueblos Indígenas. [Results of the survey on national socioeconomic characterization, Indigenous peoples]. Retrieved from http://www.mideplan.cl/final/ categoria. php? secid $=25 \&$ catid $=124$

Morgan, B. (2004). Teacher identity as pedagogy: Towards a field-internal conceptualization in bilingual and second language education. In J. BruttGriffler \& M. Varghese (Eds.), Re-writing bilingualism and the bilingual educator's knowledge base (pp. 80-96). Clevedon, UK: Multilingual Matters.

Ojeda, W. (2009). Urban ethnicity in Santiago de Chile: Mapuche migration and urban space (Doctoral dissertation). Technical University of Berlin, Berlin, Germany. Retrieved from https://opus4.kobv.de/opus4-tuberlin/frontdoor/ index/index/docld/2156

Olate, A., \& Henríquez, M. (2010). Actitudes lingüísticas de profesores mapuche de educación básica: Vigencia y enseñanza del mapudungun en el contexto educativo [Mapuche language attitudes of teachers of elementary levels: Validity and teaching of Mapudungun in the educational context]. Literatura y Lingüística, 22, 103-116. doi: 10.4067/S0716-58112010000200008

Ortiz, P. R. (2008). Intercultural Bilingual Education, Indigenous knowledge and the construction of ethnic identity: An ethnography of a Mapuche school in Chile. Retrieved from ProQuest Digital Dissertations (AAT 3277602)

Pavlenko, A. (2003). "I never knew I was bilingual”: Re-imagining teacher identities in TESOL. Journal of Language, Identity and Education, 2, 251-268.

Programa de Educación Intercultural Bilingüe, Ministerio de Educación \&UNICEF (2012). Educación para preservar nuestra diversidad cultural. Desafíos de la implementación del sector de lengua indígena en Chile [Education to preserve our cultural diversity. Challenges to implement the Indigenous language area in Chile] Santiago, Chile. Retrieved from http://www.mineduc.cl/usuarios/intercultural/doc/201304021509350.Estudi o_Implementacion_Sector_Lengua_Indigena\%282012\%29.pdf

Quilaqueo, D., \& Quintriqueo, S. (2008). Formación docente en educación intercultural para contexto mapuche en Chile [Training teachers in intercultural education for Mapuche context in Chile]. Cuadernos Interculturales, 6(10), 91-110. 
Quilaqueo, D., \& Quintriqueo, S. (2010). Saberes educativos mapuches: Un análisis desde la perspectiva de los 'kimches' [Mapuche educational knowledge: An analysis from the perspective 'kimches']. Polis, Revista de la Universidad Bolivariana, 9(26), 337- 360.

Quintrileo, C., Yáñez, C., \& Valenzuela, C. (2013). Alcances sobre la propuesta en consulta del programa de educación intercultural bilingüe (PEIB) en Chile [Scope of the proposal in consultation with regards intercultural bilingual education program (PEIB) in Chile]. LOGOS Revista de Lingüística, Filosofía y Literatura, 23(1), 45- 64.

Quintero, M., \& Crespo, P. (2006). Alcances regionales de la formación y capacitación docente para la educación intercultural bilingüe [Regional significance of teacher education and training for intercultural and bilingual education]. Quito, Ecuador: UNICEF. Retrieved from http://www.bvcooperacion.pe/biblioteca/handle/123456789/4308

Quintriqueo, S. 2009. Posibilidades y limitaciones de la educación intercultural en contexto Mapuche [Possibilities and limitations of intercultural education in Mapuche context]. Revista CUHSO, 17(1), 21-33. doi: 10.7770/cuhsoV17N1-art289

Red EIB Chile. (2011). Informe del encuentro de estudiantes de lenguas indígenas: "Hacia la construcción de un marco común de referencia para la enseñanza de las lenguas indígenas en Chile" [Report of meeting with Indigenous languages students: "Towards the construction of a common frame of reference for the teaching of Indigenous languages in Chile"]. Santiago, CL: Ediciones Red EIB Chile.

Relmuan, M. (2001). El contexto de uso en seis tipos de discurso mapuche y su posible inserción en el aula y la formación mapuche. [The context of the use of six types of Mapuche discourses and its possible inclusion in classrooms and Mapuche teacher formation] (Unpublished Master's dissertation). Universidad Mayor de San Simón, Proeib Andes, Bolivia.

Rogoff, B. (1995). Sociocultural activity on three planes. In J. V. Wertsch, P. Del Rio, \& A. Alvarez (Eds.), Sociocultural studies of mind (pp. 139-164). New York, NY: Cambridge University Press.

Schmelkes, S. (2007). Educación intercultural. Dirección General de Educación Intercultural Bilingüe. Distrito Federal, México: SEP.

Serrano, J. (1998). El papel del maestro en la Educación Intercultural Bilingüe [The teachers' role in Intercultural and Bilingual Education]. Revista Iberoamericana de Educación, 17, 91-104.

Trapnell, L. A. (2003). Some key issues in intercultural bilingual education teacher training programmes as seen from a teacher training programme in the Peruvian Amazon Basin. Comparative Education, 39(2), 165-83. 
Trapnell, L. (2011). Desde la Amazonía peruana: Aportes para la formación docente en la especialidad de educación inicial intercultural bilingüe [From the Peruvian Amazonia: Contributions for teacher education in initial and intercultural and bilingual education]. Educación/Pontificia Universidad Católica Del Perú, 20(39), 37-50.

Turra, O., Ferrada, D., \& Villena, A. (2013). La especificidad del contexto indígena como requerimiento para la formación inicial del profesorado [The specificity of Indigenous context as a requirement for initial teacher training]. Estudios Pedagógicos (Valdivia), 39(2), 329-339.

United Nations Children's Fund [UNICEF] \& Ministerio de Desarrollo Social. (2011). Incluir, sumar y escuchar. Infancia y adolescencia indígena. [Include, add and listen. Indigenous infancy and adolescence]. Retrieved from http://www.unicef.org/lac/Incluir Sumar y Escuchar WEB.pdf

Varghese, M. (2000). Bilingual teachers-in-the-making: Advocates, classroom teachers, and transients. Unpublished doctoral dissertation, University of Pennsylvania, Philadelphia, PA.

Varghese, M., Morgan, B., Johnson, B., \& Johnson, K. (2005). Theorizing language teacher identity: Three perspectives and beyond. Journal of Language, Identity, and Education, 4(1), 21-44.

Veintie, T., \& Holm, G. (2010). The perceptions of knowledge and learning of Amazonian Indigenous teacher education students. Ethnography and Education, 5(3), 325-343.

Villegas, A. M., \& Lucas, T. (2002). Preparing culturally responsive teachers: Rethinking the curriculum. Journal of teacher education, 53(1), 20-32.

Yin, R. K. (2009). Case study research: Design and methods. Los Angeles, CA: Sage.

Walsh, C. 2010. Interculturalidad crítica y educación intercultural [Critical interculturality and intercultural education]. In J. Viaña, L., Tapia, \& C. Walsh (Eds), Construyendo interculturalidad crítica [Building critical interculturalism] (pp. 75-96). Bello, BO: Instituto Internacional de Integración Andrés.

Williamson, G., Pérez, I., Collia, G., Modesto, F., \& Raín, N. (2012). Docentes rurales, infancia y adolescencia mapuche [Rural teachers, Mapuche infancy and adolescence]. Psicoperspectivas, 11(2), 77-96. Retrieved from http://www.psicoperspectivas.cl

Williamson, G. (2012). Institucionalización de la educación intercultural bilingüe en Chile. Notas y observaciones críticas [Institutionalization of intercultural and bilingual education in Chile. Notes and critical observations]. Perfiles educativos, XXXIV, 138, 126-147.

Wolcott, H. F. (1997). Ethnographic research in education. In R. M. Jaeger (Ed.), 
Complementary methods for research in education (2nd ed., pp. 327-364). Washington, DC: American Educational Research Association.

Zeichner, K. (2010). Rethinking the connections between campus courses and field experiences in college and university-based teacher education. Journal of Teacher Education, 61, 89-99. doi: 10.1177/ 0022487109347671

Zeichner K., \& Melnick S. (1996). The role of community field experiences in preparing teachers for cultural diversity." In K. Zeichner, S. Melnick, \& M. Gomez (Eds.), Currents of reform in preservice teacher education (pp. 176196). New York, NY: Teachers College Press.

\section{Author Contact}

Rukmini Becerra-Lubies: rukminib@uw.edu

Pontificia Universidad Católica de Chile, Bernardo O'Higgins 501 - Villarrica, Chile

Aliza Fones: akf7@uw.edu

University of Washington, Box 355852, 1410 NE Campus Parkway, Seattle WA, 98195-5852, USA 